Subject Lessons 


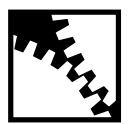

POLITICS, HISTORY, AND CULTURE

A series from the International Institute at the University of Michigan

SERIES EDITORS

George Steinmetz and Julia Adams

SERIES EDITORIAL ADVISORY BOARD

Fernando Coronil

Mamadou Diouf

Michael Dutton

Geoff Eley

Fatma Müge Göcek

Nancy Rose Hunt

Andreas Kalyvas

Webb Keane

David Laitin

Lydia Liu

Julie Skurski

Margaret Somers

Ann Laura Stoler

Katherine Verdery

Elizabeth Wingrove

Sponsored by the International Institute at the University of Michigan and published by Duke University Press, this series is centered around cultural and historical studies of power, politics, and the state-a field that cuts across the disciplines of history, sociology, anthropology, political science, and cultural studies. The focus on the relationship between state and culture refers both to a methodological approach - the study of politics and the state using culturalist methods - and a substantive one that treats signifying practices as an essential dimension of politics. The dialectic of politics, culture, and history figures prominently in all the books selected for the series. 


\title{
Subject Lessons
}

The Western Education of Colonial India

\author{
Sanjay Seth
}

Duke University Press

Durham and London 
(C) 2007 Duke University Press

All rights reserved.

Printed in the United States of America on acid-free paper @ Typeset in Trinité by Tseng Information Systems, Inc.

Library of Congress Cataloging-in-Publication Data appear on the last printed page of this book. 
To Raju and Nishad 
